\title{
Skin groups and Onan: computer simulation as an aid to understanding anthropological phenomena
}

\author{
A.H. Dekker \\ Dekker Consulting, P.O. Box 3925, Manuka, ACT, 2603, Australia \\ Email:dekker@acm.org
}

\begin{abstract}
When studying anthropological and social phenomena, it is important to evaluate them on their own terms. Agent-based computer simulation is a tool that can assist with understanding the function of such phenomena in the context of the social fabric of which they are part. Simulating key aspects of a society with and without a particular feature allows us to answer the question "what does this feature actually do?"

In this paper we demonstrate the utility of agent-based computer simulation in this regard by exploring two quite different social phenomena: Australian Aboriginal "skin groups" and the "levirate duty" of the ancient Hebrews. In both cases, the context of the phenomena (in each case, a sacred foundational story and a law) suggests a degree of importance.
\end{abstract}

Australian Aboriginal "skin groups" are intimately involved with ceremony and society in many ways. In particular, they restrict allowable marriage and they play a part in the transmission of oral culture. The agentbased NetLogo simulation reported here showed that the "skin group" system has genetic benefits, in that it reduces the death rate due to recessive lethal genes. It does this primarily by encouraging exogamy. It also increases the survival rate of stories which encode knowledge vital to a tribe's long-term survival.

Our skin group simulation used one particular well-documented skin group system, that of the Lardil people. This system has the structure of the dihedral group $D_{4}$. We compared this "skin group" system (with and without allowing women to marry older men) against two simple incest taboos. Our simulation included births, marriages, genetics, and the transmission of stories. Table 1 summarises the results of this simulation.

We also simulated the effect of the "levirate duty" of the ancient Hebrews, which is recorded in the Hebrew Scriptures (among other places, in the story of Onan), but which pre-dates that written account. Our simulation included births, property, and marriages, as well as ancient Hebrew inheritance laws and incest taboos. This simulation was less conclusive, showing little effect of the "levirate duty" on social inequality (as measured by the Gini coefficient). This provides weak support for theories indicating that it had some other purpose than social justice (such as providing children to childless widows, or providing a kind of spiritual continuity to childless men).

In both case studies, however, the phenomena could be successfully modelled using an agent-based simulation, and the results of the simulation shed useful light on the purposes of the phenomena being examined.

Table 1. Values and 95\% confidence intervals for simulation outputs of our Australian Aboriginal "skin group" simulation.

\begin{tabular}{|l|c|c|c|c|}
\hline & \multicolumn{2}{|c|}{$\begin{array}{c}\text { Simple incest taboos } \\
\text { No siblings }\end{array}$} & \multicolumn{2}{c|}{$\begin{array}{c}\text { Skin groups } \\
\text { With marriage to elders }\end{array}$} \\
\hline $\begin{array}{l}\text { Death rate due to recessive } \\
\text { lethal genes (per 100,000) }\end{array}$ & $\mathbf{5 0 0 . 5}$ & $\mathbf{4 8 2 . 0}$ & $\mathbf{5 3 . 6}$ & $\mathbf{1 4 6 . 3}$ \\
\hline $\begin{array}{l}\text { Percentage of marriage with } \\
\text { outsiders (exogamy) }\end{array}$ & $(490.8-510.1)$ & $(472.9-491.0)$ & $(49.2-57.8)$ & $(139.1-153.2)$ \\
\hline $\begin{array}{l}\text { Mean number of surviving stories } \\
\text { (transmitted in the paternal line) }\end{array}$ & $\mathbf{4 . 2 3 \%}$ & $\mathbf{4 . 2 6 \%}$ & $\mathbf{5 1 . 1 \%}$ & $\mathbf{2 4 . 1 \%}$ \\
$(0.51-0.826)$ & $(4.23-4.29)$ & $(50.1-52.1)$ & $(23.2-24.9)$ \\
\hline
\end{tabular}

Keywords: Agent-based modelling, NetLogo, Anthropology, Skin groups, Levirate marriage 
Dekker, Skin groups and Onan: computer simulation as an aid to understanding anthropological phenomena

\section{INTRODUCTION}

In the study of anthropological and social phenomena, it is important to evaluate them on their own terms, in the context of the society in which they fit. This is all the more true when the phenomena appear strange to an observer who comes from a different culture, or who is many centuries or millennia distant in time.

Agent-based computer simulation can assist with this. Agent-based models represent each group or individual within a society using state variables and some computer code. Decisions, actions, and interactions by the group or individual relevant to the issue being studied can thus be explicitly represented, and the effect of changing these decisions, actions, and interactions can be studied. Agent-based simulation can thus be used to obtain an increased understanding of social phenomena (Gilbert and Troitzsch, 2005) and has been successfully applied in answering anthropological questions (Axtell et al., 2002; Rorabaugh, 2015).

In this paper we demonstrate how agent-based computer simulation can help in understanding the function of anthropological and social phenomena by answering the question "what would happen if this phenomenon was not present?"

We do this by exploring two quite different social phenomena: first, Australian Aboriginal "skin groups," which remain important today; and second, the "levirate duty" of the ancient Hebrews, which dates back several thousand years, but which has been recorded in written form in the Hebrew Scriptures. Both phenomena are associated with indicators that they are important (in some sense), and so both raise interesting questions of function and purpose.

\section{SKIN GROUPS}

\subsection{Skin groups and Aboriginal culture}

"Skin group" systems form an important part of Australian Aboriginal culture. They are intimately involved with ceremony and society in many ways. They also control marriage: members of skin group $A$ may only have sexual relations with a designated partner skin group $B$, and the resulting children will have skin group $C$ (or possibly skin groups $C$ for girls and $D$ for boys).

There are strong taboos against sexual relations outside the designated partner skin group, and these are reinforced by traditional stories. For example, the stories about the Seven Sisters (Pleiades) told in the western part of Australia communicate a great deal of information about the origin and geography of the land, but the core of the stories concerns the skin group taboo. The seven sisters flee across the land, and ultimately into the sky, because they are pursued by a man who is outside their designated partner skin group (Wroth, 2015; Neale, 2017). Up until recent

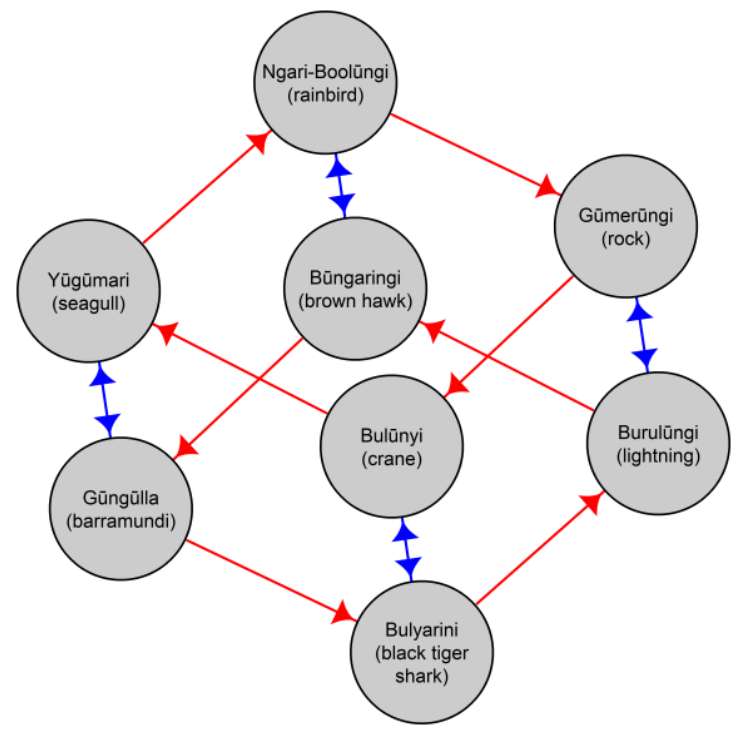

Figure 1. The 8 skin groups of the Lardil people (with associated totems). Single-headed red arrows run from mother to child $(\mu)$, and double-headed blue arrows run between father and child $(\phi)$.

times, these taboos were reinforced by strict penalties, up to and including death (Smith, 2004). Being reinforced both by stories and by strict penalties, these taboos must be important. But what function do they perform within traditional aboriginal society? Computer simulation can help to answer this question.

A variety of skin group systems, with 2, 4, 8, or 16 groups, exist in Australia. As a representative system, this paper focuses on the 8-group system used by the Lardil people of Mornington Island, Queensland (McKnight, 1999). The documentation of this system by Binnion (1987) has been endorsed by the Lardil people themselves. Figure 1 and Figure 2 shows the 8 Lardil skin groups. The function $\mu$ (red arrows) maps the skin group of the mother to the skin group of her child, while the function $\phi$ (blue arrows) maps the skin group of the father to the skin group of his child. We have $\phi^{2}=i$ (where $i$ is the identity function). That is, every person's skin group is the same as their paternal grandfather. We also have $\mu^{4}=i$ (i.e. maternal descent follows a 4-cycle) and $\mu \phi \mu=\phi$, making this structure equivalent to the dihedral group $D_{4}$, the group of symmetries of the square (Humphreys, 1996). The designated partners for any skin group can be found by following a red arrow and then a blue one in Figure 1. 


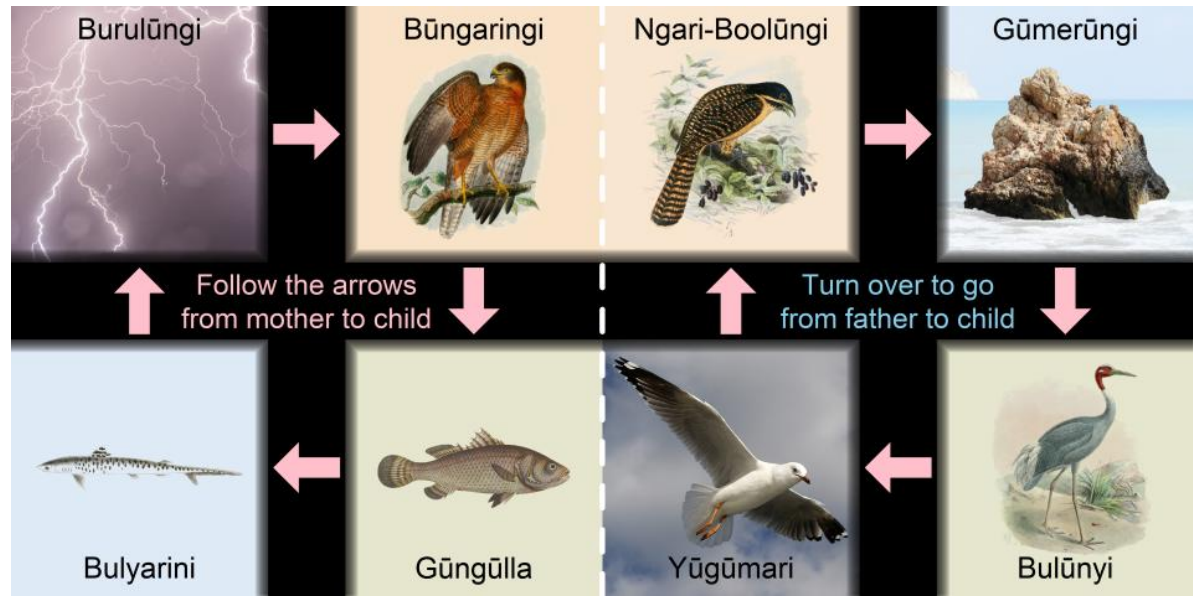

Figure 2. Cutting out this image and folding on the dotted line gives an alternative model of Lardil skin groups. Pink arrows correspond to the red arrows in Figure 1.

\subsection{Simulating skin groups (genetics)}

We explore the function of the skin group system using a simulation written in NetLogo (Wilensky, 1999). We simulate a tribe of initially 100 people, with a fertility rate such that the population grows until it oscillates around a mean of 212. A population of this size is not viable in the long term, but the tribe is assumed to form part of a much larger people-group. If members of the tribe cannot find skin-appropriate partners within the tribe, they can therefore often find them outside. Given the difficulties inherent in this, and the fact that it was rare for Aboriginal women to be unmarried (Berndt and Berndt, 1985), this seeking of outside partners was assumed to be successful $75 \%$ of the time. The simulation runs for 300 generations.

The simulation includes a simple genetic model. Each simulated person has 68,000 base pairs where mutations can lead to recessive lethal disorders, and an average of 0.29 such mutations per haploid set, as per Gao et al. (2015). The relevant genome was represented as a list of numerical indices of mutated loci. The number of deaths due to those recessive lethal genes was recorded during the simulation experiment. A mutation rate of 1 per 200 births kept the genetic load roughly constant.

In the basic simulation ("skin groups"), young women partner skin-appropriate young men of the same generation. In a variation ("skin + elders") they may also partner older men from the previous two generations, which may be more realistic (Fry, 1934). For comparison, we also replace the skin group systems by two basic incest taboos: a loose one forbidding only marrying siblings ("no siblings") and a stricter one also forbidding marrying first cousins ("no cousins"). We ran each of the 4 variations 500 times.

\subsection{Results and Discussion (genetics)}

Results of the simulation are shown in Figure 3 and Figure 4. The key outcome was the death rate due to recessive lethal genes. This was $\mathbf{5 0 0 . 5}$ per $\mathbf{1 0 0 , 0 0 0}$ for the looser incest taboo $(95 \%$ confidence interval by bootstrap 490.8-510.1), and a slightly lower $\mathbf{4 8 2 . 0}$ for the stricter incest taboo (95\% c.i. 472.9-491.0). In comparison, it was only $\mathbf{5 3 . 6}$ per $\mathbf{1 0 0 , 0 0 0}$ for the basic skin group system (95\% c.i. $49.2-57.8$ ) and a somewhat higher $\mathbf{1 4 6 . 3}$ for the skin group system where women may partner elders (95\% c.i. 139.1-153.2).

The enormous genetic benefit of the skin group system is primarily due to exogamy, as suggested by White and Denham (2007) and McConvell (2018). Marriages with unrelated outsiders bring in new genetic material and reduce the death rate due to recessive lethal genes. The strict rules of the skin group system create people who can find no skin-appropriate partner within the tribe, and must therefore make the effort to find skinappropriate partners in the wider people-group.

The percentage of marriage with outsiders was only $\mathbf{4 . 2 3 \%}$ for the looser incest taboo (95\% c.i. $4.20-4.26$ ), and $\mathbf{4 . 2 6 \%}$ for the stricter incest taboo (95\% c.i. 4.23-4.29). In comparison, it was $\mathbf{5 1 . 1 \%}$ for the basic skin group system (95\% c.i. 50.1-52.1) and a somewhat lower $\mathbf{2 4 . 1 \%}$ for the skin group system with marriage to elders (95\% c.i. $23.2-24.9)$.

Where marriage to elders was permitted, $36.7 \%$ of marriages were of that form (95\% c.i. $36.2-37.3$ ).

It should be noted that the simulation treats outsiders as being completely unrelated, genetically. This is not entirely realistic, which means that the benefit of exogamy will be less than our simulation suggests. 


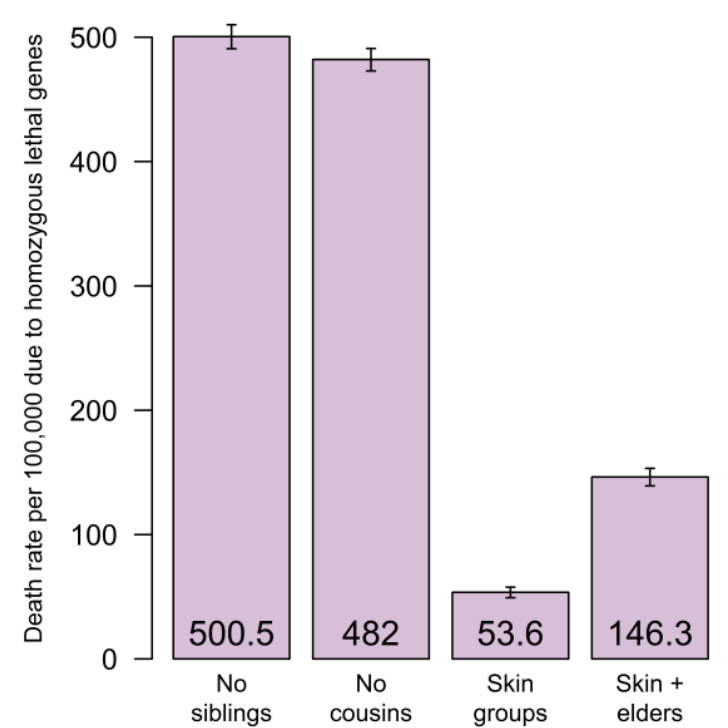

Figure 3. Simulated death rates due recessive lethal genes for two incest taboos compared to skin group systems without and with marriage to elders.

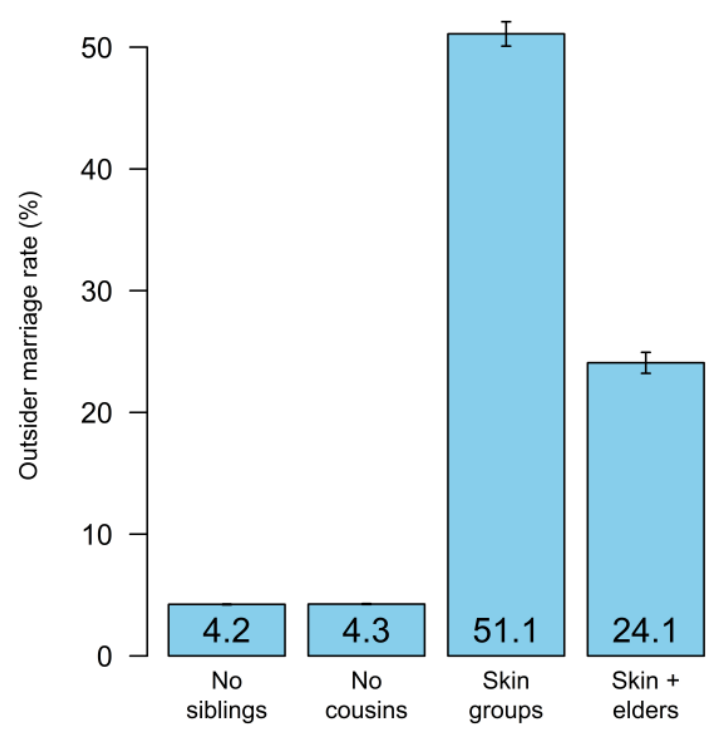

Figure 4. Percentages of marriage to outsiders for two incest taboos compared to skin group systems without and with marriage to elders.

\subsection{Skin groups and stories}

As well as having a genetic benefit, skin groups play an important part in the transmission of traditional stories (such as those of the Seven Sisters). For some stories, the men, or for other stories, the women, of two or more skin groups will be custodians. Stories passed from father to son, for from paternal aunt to niece, will follow the blue arrows in Figure 2. Stories passed from mother to daughter, or from maternal uncle to nephew, will follow the red arrows. There can be 8 simultaneous blue cycles of stories ( 4 for men and 4 for women), and 4 simultaneous red cycles of stories. These stories encode knowledge vital to the tribe's longterm survival, such as the location of waterholes (Neale, 2017).

Should all the living members of a blue cycle die, their stories will die with them (even though, due to the red cycles, children of those skin groups will eventually be born).

\subsection{Simulating story transmission}

For the simulation reported in Figure 5, we simulated 8 stories passed along blue cycles (4 passed from father to son, and 4 passed from paternal aunt to niece). Story transmission was by skin group, even when marriage was controlled only by incest taboo. Partners brought in from outside were assumed not to bring in stories (should they do so, this would be an additional benefit of exogamy). Once again, we ran the simulation for 300 generations, and 500 times for each of the four variations.

The mean number of surviving stories was only 0.70 for the looser incest taboo $(95 \%$ c.i. $0.51-$ $0.88)$, and $\mathbf{0 . 9 1}$ for the stricter incest taboo $(95 \%$ c.i. 0.70-1.11). In comparison, a mean of $\mathbf{7 . 1 9}$ stories survived for the basic skin group system (95\% c.i. 7.04-7.36) and a mean of $\mathbf{7 . 8 7}$ stories survived for the skin group system with marriage to elders (95\% c.i. $7.82-7.94)$. For that last case, all 8 stories survived $96 \%$ of the time.

As well as providing genetic benefits through encouraging exogamy, the skin group system thus facilitates the survival of stories which encode knowledge vital to the long-term survival of the tribe. 
Dekker, Skin groups and Onan: computer simulation as an aid to understanding anthropological phenomena

\section{ONAN AND THE LEVIRATE DUTY}

\subsection{The levirate duty in the Hebrew Scriptures}

The Hebrew Scriptures or Tanakh (known to Christians as the Old Testament) describes the ancient Hebrew people as nomadic herders, who eventually settled down to a life of subsistence agriculture in the land that came to be called Israel.

One of the more unusual ancient Hebrew customs, which seems to date from the nomadic period, is that of the levirate duty. The brother-in-law (Latin levir) of a childless widow was required to get the widow pregnant with a child who would be considered the heir of her deceased husband.

In the law described in Deuteronomy 25:5-10, the duty appears not to be compulsory (although it prescribes a ritualistic spitting by the widow in the face of a levir who fails to perform his duty). By Talmudic times the duty was viewed somewhat negatively (Singer, 1906), although it continued to be practiced by Sephardic Jewish communities up until the $20^{\text {th }}$ century. When first mentioned in Genesis 38:6-10, however, the duty is described as so important that God strikes down dead Onan, the man who refuses to carry it out:

"Judah got a wife for Er, his firstborn, and her name was Tamar. But Er, Judah's firstborn, was wicked in the LORD's sight; so the LORD put him to death.

Then Judah said to Onan, 'Sleep with your brother's wife and fulfill your duty to her as a brother-in-law to raise up offspring for your brother.' But Onan knew that the child would not be his; so whenever he slept with his brother's wife, he spilled his semen on the ground to keep from providing offspring for his brother. What he did was wicked in the LORD's sight; so the LORD put him to death also." 1

The combination of the law in Deuteronomy 25:5-10 and the foundational story in Genesis 38:6-10 suggests that the levirate duty was extremely important, which raises the question of what function it performed in ancient Hebrew society.

One suggestion is that the duty had a spiritual significance: that having a child (even after death) provided a form of immortality to the deceased husband (Keil and Delitzsch, 1885, on Deuteronomy; Leggett, 1974). In line with this theory is the way in which 2 Samuel 18:18 describes a monument being erected by a man who has "no son to carry on the memory of my name" (Keil and Delitzsch, 1880). Similarly Isaiah 56:3-5 suggests that religious observance provides "a memorial and a name better than sons and daughters" to eunuchs who can have no children.

An alternate explanation is that the benefit was primarily to the widow, who obtained a child as a result (Davies, 1981; Hiers 2009). This is the impression given by the book of Ruth, in which a modified form of the levirate duty plays a major part (Dekker and Dekker, 2018). Indeed, the climax of that story seems to be the line "Naomi has a son!" (Ruth 4:17).

A third explanation is that the duty concerns social justice, in that the levir is prevented from adding his dead brother's property to that which he already owns. This third option is amenable to exploration using computer simulation.

Finally, the purpose of the duty may have changed over time (Burrows, 1940).

\subsection{Simulating the levirate duty}

We again use a simulation written in NetLogo (Wilensky, 1999) to explore the levirate duty. We simulate 16 generations of a population that starts at 20 (with property initially distributed equally) and grows exponentially. Our simulation includes the incest taboos in the Hebrew Scriptures (Leviticus 18:9-13), as well as the property division rules, which give a double portion of the inheritance to the firstborn son (Deuteronomy 21:17) and which otherwise distribute the property as per Numbers 27:8-11:

“... If a man dies and leaves no son, give his inheritance to his daughter. If he has no daughter, give his inheritance to his brothers. If he has no brothers, give his inheritance to his father's brothers. If his father had no brothers, give his inheritance to the nearest relative in his clan, that he may possess it...."

\footnotetext{
${ }^{1}$ Scripture quotations taken from The Holy Bible, New International Version ${ }^{\circledR}$ NIV ${ }^{\circledR}$ Copyright $\odot 1973197819842011$ by Biblica, Inc. ${ }^{\mathrm{TM}}$ Used by permission. All rights reserved worldwide.
} 
To implement these rules, a population tree of both living and dead members was built during the simulation, so the required heir could be found by navigating the tree.

The probability of producing an heir via the levirate duty was varied from 0 (equivalent to not implementing the levirate duty at all) to $0.3,0.6,0.7,0.75,0.8$, and 0.9. Each option was run 100 times, and the Gini coefficient (Arnold, 2008) was calculated at the end of each run as a measure of wealth inequality.

\subsection{Results and Discussion}

As the probability of producing an heir via the levirate duty increased from 0 to 0.3 to 0.6 , the mean Gini coefficient increased from 0.70 to 0.71 to 0.73 , as shown in Figure 6 . At a probability of 0.7 or above, the Gini coefficient stabilised at a mean of 0.745 . This increase in wealth inequality was statistically significant $\left(p<10^{-8}\right)$, although it was quite small.

The fact that the levirate duty did not lead to a decrease in wealth inequality casts doubt on the idea that the levirate duty had a social justice role, at least at the time that the laws in the books of Deuteronomy and Numbers were formulated. In turn, this provides weak support for the suggestions that the duty had a spiritual significance or that its primary function was to give a child to the widow. Unfortunately, there seems no obvious way in which computer simulation could help decide between those alternatives.

It should also be noted that a number of other societies have or have had customs similar to the levirate duty. However, the levirate duty may have a different function in those societies (Weisberg, 2009). Each such custom would need to be evaluated in the context of its own social fabric.

\section{GENERAL DISCUSSION AND CONCLUSION}

We have investigated two quite different social phenomena: first, one version of the skin group systems in force among Australian Aboriginals, and second, the levirate duty of the ancient Hebrews. Both phenomena are supported by a sacred foundational story and a law, suggesting a degree of importance for the phenomena. In both cases, we used computer simulation to investigate the purpose of the phenomena within their social contexts, by simulating the effect of their removal. For the simulation of the levirate duty, this involved simulating ancient Hebrew inheritance law, which is codified in the Hebrew Scriptures (although the levirate duty itself is significantly older than the written account).

Our skin group simulation used one particular skin group system, that of the Lardil people, shown in Figure 1 and Figure 2. This system has the structure of the dihedral group $D_{4}$ (it is a question for further research whether this is superior to the group $C_{4} \times C_{2}$, which would have one of the loops in Figure 1 going in the opposite direction).

Our simulation showed a substantial genetic advantage for the skin group system, with the death rate due to recessive lethal genes being either $11 \%$ that of a no-cousins incest taboo if marriage of women to older men was excluded, and $30 \%$ if it was permitted. This genetic benefit of the skin group system was primarily due to it creating an exogamy incentive, as suggested by White and Denham (2007) and McConvell (2018). Marriages to outsiders 5.7 were times as common as with a no-cousins incest taboo (if marriage of women to older men was excluded), and 12 times (if it was permitted).

In addition, the simulation showed the skin group system supporting the transmission of potentially lifesaving tribal knowledge in the form of stories, with stories transmitted along the paternal line surviving $90 \%$ of the time if marriage of women to older men was excluded, and $98 \%$ of the time if it was permitted, compared to only $11 \%$ of the time with a no-cousins incest taboo. 
Dekker, Skin groups and Onan: computer simulation as an aid to understanding anthropological phenomena

The skin group system is thus, for two different reasons, revealed to be a vital survival mechanism for people living in an at times harsh environment.

Our simulation of the ancient Hebrew levirate duty was less conclusive, in spite of the advantages of having an ancient written account as a source of information. The levirate duty had only a small effect on wealth inequality, as measured by the Gini coefficient, and therefore was unlikely to serve a social justice role. This provides weak support for the alternate theories that it had a spiritual significance, or that its primary purpose was to benefit widows by giving them a child.

In both cases, however, we have been able to successfully explore the function of social phenomena by simulating relevant aspects of the social fabric in which they fit, including marriage, children, story transmission, and inheritance of property. It is also possible for agent-based social simulations to incorporate hunting, agriculture, belief in propositions, trust in people, friendship, obligation, transfer of gifts, prestige, and other aspects of the social fabric. Placing a phenomenon of interest in the context of such a social fabric allows us to answer the question "what would happen if this phenomenon was not present?"

\section{REFERENCES}

Arnold, R.A. (2008). Economics, p. 578. Thomson Higher Education.

Axtell, R.L., Epstein, J.M., Dean, J.S., Gumerman, G.J., Swedlund, A.C., Harburger, J., Chakravarty, S., Hammond, R., Parker, J., and Parker, M. (2002). Population growth and collapse in a multiagent model of the Kayenta Anasazi in Long House Valley, PNAS 99 (suppl 3), 7275-7279, doi: 10.1073/pnas.092080799

Berndt, R.M. and Berndt, C.H. (1985). The World of the First Australians. Rigby, Adelaide.

Binnion, J. (1987). The Lardil people of Mornington Island (student handbook and teacher handbook). Aboriginal Community College, Port Adelaide.

Burrows, M. (1940). Levirate Marriage in Israel, Journal of Biblical Literature 59(1), 23-33.

Davies, E. W. (1981). Inheritance Rights and the Hebrew Levirate Marriage: Part 1 and Part 2. Vetus Testamentum 31, Fasc. 2, pp. 138-144 (April) and Fasc. 3, pp. 257-268 (July).

Dekker, J.T. and Dekker, A.H. (2018). Centrality in the book of Ruth. Vetus Testamentum 68 (1), 41-50.

Fry, H.K. (1934). Kinship and descent among the Australian Aborigines. Transactions of the Royal Society of South Australia 58, 14-21.

Gao, Z., Waggoner, D., Stephens, M. Ober, C., and Przeworski, M. (2015). An estimate of the average number of recessive lethal mutations carried by humans. Genetics 199(4), 1243-1254.

Gilbert, N. and Troitzsch, K. (2005). Simulation for the Social Scientist, 2nd ed. Open University Press.

Hiers, R. H. (2009). Justice and Compassion in Biblical Law, Continuum.

Humphries, J. (1996). A Course in Group Theory. Oxford University Press, Oxford.

Keil, C. F. and Delitzsch, F. (1880). Biblical Commentary on the Books of Samuel (translated by Martin, J.). T. \& T. Clark, Edinburgh.

Keil, C. F. and Delitzsch, F. (1885). Biblical Commentary on the Old Testament, Volume I: The Pentateuch (translated by Martin, J.). T. \& T. Clark, Edinburgh.

Leggett, D.A. (1974). The Levirate and Goel Institutions in the Old Testament: With special attention to the book of Ruth. Mack Publishing Company, Cherry Hill, New Jersey.

McConvell, P. (2018). Revisiting Aboriginal social organisation. Introduction to Skin, Kin and Clan: The Dynamics of Social Categories in Indigenous Australia (McConvell, P., Kelly, P., and Lacrampe, S., eds.), ANU Press.

McKnight, D. (1999). People, Countries, and the Rainbow Serpent: Systems of classification among the Lardil of Mornington Island. Oxford University Press.

Neale, M., ed. (2017). Songlines: tracking the Seven Sisters. National Museum of Australia.

Rorabaugh, A. (2015). Modeling pre-European contact Coast Salish seasonal social networks and their impacts on unbiased cultural transmission, Journal of Artificial Societies and Social Simulation 18 (4) 8 , jasss.soc.surrey.ac.uk/18/4/8.html

Singer. I., ed. (1906). Jewish Encyclopedia, Funk \& Wagnalls.

Smith, C. (2004). Country, Kin and Culture: Survival of an Australian Aboriginal Community, p 9. Wakefield Press, Adelaide.

Weisberg, D.E. (2009). Levirate Marriage and the Family in Ancient Judaism. Brandeis University Press.

White, D.R. and Denham, W.W. (2007). The Indigenous Australian marriage paradox. Third General Scholarly Meeting of the Society for Anthropological Sciences (SASci). San Antonio, Texas, Feb. 21-24.

Wilensky, U. (1999). NetLogo: ccl.northwestern.edu/netlogo. Center for Connected Learning and ComputerBased Modeling, Northwestern University, Evanston, IL.

Wroth, D. (2015). Star Dreaming Story of the Seven Sisters. Japingka Aboriginal Art Gallery, Perth. Online at japingkaaboriginalart.com/articles/star-dreaming-seven-sisters 